\title{
Contextual teaching and learning-based functional academic teaching materials for the teachers specialized in educating the students with visual impairment
}

\author{
Sayidatul Maslahah *, Ishartiwi Ishartiwi, Mumpuniarti Mumpuniarti, Yeni Irma Normawati \\ Department of Special Education, Pascasarjana, Universitas Negeri Yogyakarta \\ Jalan Colombo No. 1, Karangmalang, Yogyakarta 55281, Indonesia \\ * Corresponding Author. E-mail: sayidatulmaslahah2@gmail.com \\ Received: 16 October 2017; Revised: 1 November 2019; Accepted: 11 November 2019
}

\begin{abstract}
The objective of the study is to develop the Contextual Teaching and Learning (CTL)-based functional academic teaching materials for the teachers specialized in educating the students with visual impairment. The method that has been adopted within the conduct of the study is Research and Development (R\&D) with reference to the Borg \& Gall Model with limit on the stage. The study itself has been conducted in the Yaketunis Type A Special School, which has been the school for the students with visual impairment in Yogyakarta. The results of the study, which cover the stages of needs analysis in the given special school, show that up to date there has not been any written systematic functional academic learning. In addition, the results of the study also show that the teachers still have been dealing with the efforts of teaching the functional academic because the curriculum has been the modification of the regular curriculum. Therefore, the teachers demand the functional academic teaching materials for the students with visual impairment. Based on the results of the expert judgment by the media expert, the material expert and the test with the teacher, the functional academic teaching materials have been declared good and fit for implementation in the school. Then, the aspects that have been assessed within the expert judgment are namely material/content, presentation, linguistic and graphic. Furthermore, the score by 3.65 from the media expert and the score 3.80 from the material expert imply that the product in the form of functional academic teaching materials have been very fit and good for implementation by the teachers specialized in teaching the students with visual impairment. In addition, the response within the test stage also shows that the mean score has been 3.70; as a result, the product in the form of Contextual Teaching and Learning (CTL)-based functional academic teaching materials has been fit for implementation. In other words, it might be concluded that the Contextual Teaching and Learning (CTL)-based functional academic teaching materials have been feasible for implementation for the teachers specialized in educating the students with visual impairment in the terms of functional reading, writing and counting activities.
\end{abstract}

Keyword: functional academic, teaching materials, contextual teaching and learning, students with visual impairment

How to Cite: Maslahah, S., Ishartiwi, I., Mumpuniarti, M., \& Normawati, Y. (2019). Contextual teaching and learning-based functional academic teaching materials for the teachers specialized in educating the students with visual impairment. Jurnal Prima Edukasia, 7(2), 182-196. doi:https://doi.org/10.21831/jpe.v7i2.28738

do: https://doi.org/10.21831/jpe.v7i2.28738

\section{Introduction}

Education is the fundamental right of every individual and also serves as the tool for preparing individuals in their re-adaptation into the communal life (Sari \& Syamsi, 2015). In the same time, education might be considered as a process of persuading individuals so that they will be able to adapt themselves into the environment and to contribute something to the society as well (Hamalik, 2009, p. 79). In accordance to the objectives of education in Indonesia, which has been stated in the Law Number 20 Year 2003 on National Education System, it is obligatory that every Indonesian child should be provided by the rights to access the education sufficiently (Undang-Undang Republik Indonesia nomor 20 tahun 2003 tentang sistem pendidikan nasional, 2003). This statement is also asserted in Article 5 (2010, p.65), which states that the citizens who 
Jurnal Prima Edukasia, 7 (2), 2019 - 183

Sayidatul Maslahah, Ishartiwi Ishartiwi, Mumpuniarti Mumpuniarti, Yeni Irma Normawati

have different physical, emotional, mental, intellectual and/or social capability should be provided with the right to access education. Based on the two statements, it is clear that the children with impairment should be provided with right to access the learning process in accordance to their needs.

With regards to the above assertion, one of individuals that should be provided with the right to access education is the students with visual impairment. Visual impairment, or generally known as blindness or visual impairment, refers to the obstacles that have been caused by the loss of vision resulting in the limited information attainment (Kauffman \& Hallahan, 2011). The group of the students with visual impairment also have additional obstacle namely intelectual impairment. The presence of the so-called intellectual impairment certainly results in the limited attainment of information.

The limited attainment of information itself also influences the learning process that has specific obligatory requirements that the students with visual impairment should meet, especially the ones who also have intelectual impairment. The fulfilment of the specific obligatory requirements is important in order to accommodate the well-functioning information attainment. Then, the learning accommodation that might be well-benefitted for meeting the learning needs is the use of visual and auditory sense. The results of a study by Hötting and Röder (2009) state that within the fulfilment of the daily needs toward information a student with visual impairment relies on the auditory sense. Thus, the characteristics of the student with visual impairment who have the intellectual impaiment have implications on concrete and functional knowledge (Salekin et al., 2010, p. 98).

In addition, within the information attainment the students with visual impairment, who do not attain information through visual sense, suffer from the loss of visual perception approximately $85.00 \%$ (Rudiyati, 2002). Not to mention, the students with visual impairment who also have intellectual impairment should deal with more difficulties in attaining information. Therefore, in order to attain the in-formation well, there should be perception from other modalities (Subagya, 2019). Perception will appear if there are stimuli that have been provided (Solso et al., 2008 , p. 75). With regards to the statement, the best stimulation of a student with visual and intellectual impairment comes from the auditory sense in the first place and the tactile sense in the second place. The process of learning and attaining information should be performed by using the concrete aspects (Vygotskil \& Cole, 1978). Thus, it is expected that through such learning principle the students will enjoy the meaningful learning process (Sagala, 2009).

The appropriate learning process that might be afforded to the students with visual and intellectual impairment is the functional academic learning process. The functional academic learning process is a learning process that might assist students to master skills that will help them in adapting into the society (Bouck \& Joshi, 2012). The review coverage in the functional academic learning process is symbols or codes that might assist an individual in reading the surrounding environment (Mumpuniarti \& Pujaningsih, 2016, p. 98).

In order to support the success of the functional academic learning process, there are several learning models that might be adopted; there learning models do not only put forward the academic aspects but also the links among the school, the family and the society (Giesen et al., 2012). The link from one aspect to another becomes an important aspect. For example, the mathematical learning process should be taught by using the principle of "learning to mean" in order that through the long-term learning objectives the students might take possession of mathematical values and apply these values into the real life (Fauziyah \& Jailani, 2014). According to Bobzien (2014), children with multiple obstacles display more comfortable behaviours when they retrieve instructions in solving the academic problems. In addition to the statement, there should be appropriate programs which aim at training the students so that the students will be more independent in going through their life within the future (Smith \& Tyler, 2010). Therefore, the learning process that will be provided should have the classroom activities arranged in accordance to the context of the daily activities or the real life (Hallahan et al., 2018, p. 117).

The functional academic learning process will proceed smoothly if the school in which the functional academic learning process has been implemented possesses the relevant teaching materials and the implementable curriculum in accordance to the learning needs of the students altogether with the sufficient facilities. However, in some cases the situation might be different. With regards to the statement, the results of the preliminary study in the Yaketunis Type A Special School, the teachers implement the curricu- 
Jurnal Prima Edukasia, 7 (2), 2019 - 184

Sayidatul Maslahah, Ishartiwi Ishartiwi, Mumpuniarti Mumpuniarti, Yeni Irma Normawati

lum has been modified from the one implemented in the regular school. As a result, the teachers still have difficulties in developing the materials and also in setting the functional academic teaching process whereas the curriculum that has been implemented should set the priority on the experiences and should also be based on the activities. The reason is that the principle of the functional academic learning process is based on the direct practice and experience since the objective is to attain meaningful learning process and to develop the cognitive structure of the students independently (Light et al., 2009).

Up to date, there has not been any teaching material that might be implemented for teaching the functional academic learning process for the students with visual and intellectual impairment whereas teaching material is one of the learning process components that should be present in order to facilitate the conduct of the teachers' duty. Not to mention, teaching materials also serves as the fundamental knowledge for any individual, including the students with different capability. In relation to the situation, (Hallahan et al., 2018, p. 117) state that the learning process for the students with visual and intellectual impairment should take the form of instruction in real-life setting with real materials. The teachers should create classroom activities that have been set in the daily activities within the real life. For example, the teachers might teach the students with visual and intellectual impairment to go shopping. The contribution of the functional academic learning process is the mediation on the use of the symbols or the codes toward the phenomena taking place in the surrounding environment. The role that has been found in the functional academic learning process is also relevant to its contribution to the daily life. (Johnson, 2002, p. 24) states that the contextual learning process enables the students to link the material contents to the daily life contexts so that the learning process becomes more meaningful. Similarly, (Hartoyo, 2009) states that the implementation of the contextual learning process is able to improve the students' motivation, to improve the students' active involvement and to create fun and interesting learning situation. Therefore, by implementing the contextual learning process the students might attain direct experience. This situation is relevant to the stage of the stage of the thinking skills for the students with visual impairment, namely the concrete operational cognitive stage that has been targeted by the teachers. This stage itself refers to the information attainment that the students perform by using the concrete objects (Piaget \& Inhelder, 2010). In addition, Hauser et al. (1999) altogether state that the functional academic curriculum has been designed for the teachers or the instructors of students with impairment. However, this kind of learning process might be interrupted and less maximum in terms of information attainment. Therefore, there should be relevant teaching method, relevant learning method, adjustable learning materials and adjustable learning environment (Bandura \& Walters, 1977).

Teaching materials refer to the tools that teachers benefit in assisting the learning process so that the learning process will be more effective. Teaching materials are benefitted by the students as well so that the students might learn in a more effective fashion (Chanda et al., 2000). Teaching materials consist of contents that the students should learn in the printed form and that the teachers should facilitate in order to achieve the learning objectives (Dick et al., 2009). The important function of teaching materials is to serve as the teacher directions and guidelines in performing the learning activities within the classroom (Purnomo \& Wilujeng, 2016). With regards to the explanation, the teaching materials that will be developed throughout the course of the study are in the form of teacher's guidebook for the conduct of the functional academic learning process that might be benefitted independently by the teachers. The teacher's guidebook that will be developed is based on the Contextual Teaching and Learning (CTL) Model; consequently, the teacher's guidebook will provide learning stages linked to the daily activities. The Contextual Teaching and Learning (CTL)based functional academic learning process thus implements the syntax within the model. (Johnson, 2002) states that the syntaxes in the CTL model consists of seven components namely: (1) constructivism; (2) inquiry; (3) questioning; (4) learning community; (5) modelling; (6) reflection); and (7) authentic assessment. In other words, through the conduct of the study the Contextual Teaching and Learning (CTL)-based functional academic teaching materials might be developed in order to facilitate the teachers in providing the systematic learning process. In specific, through the conduct of the study the Contextual Teaching and Learning (CTL)-based functional academic teaching materials for the teachers of the students with visual impairment might be developed. 
Jurnal Prima Edukasia, 7 (2), 2019 - 185

Sayidatul Maslahah, Ishartiwi Ishartiwi, Mumpuniarti Mumpuniarti, Yeni Irma Normawati

\section{Method}

The study was designed in the form of Research and Development with reference to the Borg \& Gall development model (Gall et al., 2003) consisting of 10 stages. However, within the conduct of study only nine stages had been adopted namely: (1) information gathering and preliminary study; (2) planning; (3) product draft development; (4) small-scale test; (5) revision based on small-scale test results; (6) field test; (7) revision based on the field test results; (8) operational field test; and (9) final product revision (Indaryati \& Jailani, 2015; Prasetyo, 2017; Purnomo \& Wilujeng, 2016).

Then, the details on the stage of the study might be elaborated further. In the first stage, namely Information Gathering and Preliminary Study, the activities that had been conducted were: (1) identifying the needs or the curricula that might be implemented in the learning activities; (2) analysing the learning sets that might be implemented in the learning process; and (3) performing learning needs assessment and analysis so that the learning programs that had been designed might meet the students' potentials. Then, in the second stage, namely Planning, the activities that had been conducted were: (1) defining the content; (2) sorting the content materials in accordance to the competence map; (3) composing the functional academic materials in the form of summary and inserting the summary into the prototype; and (4) defining the exercise form for the functional academic materials. Next, in the third stage, namely Product Draft Development, the activities that had been conducted were: (1) developing the product in accordance to the prototype, which covered competence map; (2) compiling the materials, which consisted of the concept of students with visual impairment, functional academic, contextual teaching and learning, lesson plan, evaluation and references; (3) developing the cover of the teaching materials; and (4) designing the logo and the cover of the product.

Moving to the fourth stage, namely SmallScale Test, the activities that had been conducted were testing the product. The test of the product involved the media expert and the materials expert. Within the conduct of the product test, the media expert was a lecturer of learning technology majoring in the teaching material development. The duty of the media expert was to test the display of the product. In addition, the test of the product also involved material expert. The material expert conducted the test by means of professional judgment for the domain of students with impairment. The professional judgment itself took the form of questionnaire completion and the questionnaire was provided by the lecturer. Eventually, the product was validated by a lecturer of Special Education as the material expert and the lecturer of Educational Technology as the media expert. After the fourth stage had been completed, the study progressed to the fifth stage, namely Preliminary Field Test, which activities were testing the draft of the product, namely the teaching materials that had been developed, to three teachers in Yaketunis Type A Special School. The preliminary field test was conducted by completing the questionnaire that had been prepared by the researcher. In this stage, the subjects paid attention closely to the teaching materials and assigned certain scores based on the criteria in each aspect. Based on the assessment results, the feedback and the comment that had been gathered in the Pre-liminary Field Test should be inputted into the sixth stage namely Main Product Revision. Afterward, the product was sent to the seventh stage namely Field Operational Test, which involved 6 special teachers from the Yaketunis Type A Special School. Last but not the least, the product was revised by improving the CTL-based teaching materials with reference to the assessment, the feedback and the comment that had been found in the Operational Field Test.

The study took place about seven months from March 2019 until October 2019 in the Yaketunis Type A Special School located in Parangtritis Street Number 46, Mantrijeron, District of Mantrijeron, City of Yogyakarya. The subjects in the study were the special teachers for the students with visual impairment. Three teachers were involved in the Preliminary Test and later six teachers were involved in the Field Test. Then, the developers of the teaching materials or the product of the study were the student and the lecturers of Department of Special Education, Pascasarjana, Universitas Negeri Yogyakarta.

The data that had been attained in the study were the research data, the product development process data, the product fitness data and the test data. In gathering the data, the data gathering techniques that had been implemented were interview, observation, questionnaire and expert validation. Then, the data that had been retrieved from the preliminary study were analysed by using the descriptive qualitative analysis tech- 
nique. According to Miles et al. (2014), the conduct of the descriptive qualitative analysis technique consists of three stages namely: (1) data condensation; (2) data display; and (3) conclusion drawing/verification. Furthermore, the data that had been retrieved from the interview guideline, the product assessment sheet, the observation sheet, the test and the questionnaire were analysed by using both the qualitative and the quantitative statistical analysis technique. The data alone were attained from: (1) results of interview with the teachers; (2) feedback from the material expert, the media expert and the advisor; and (3) results of observation. After the data had been attained completely, the data were processed and analysed qualitatively in order to identify the revision for the product in the near future. Furthermore, the data on the product fitness were analysed by using percentage. Last but not the least, the quantitative data in the research and development initiative consisted of: (1) assessment score by the material expert; (2) assessment score by the media expert; (3) assessment score by the teacher; (4) assessment on the observation results; and (5) score on the results of interview with the teachers and the students. The assessment was considered good when the minimum score that should be achieved has been good.

\section{Results and Discussions}

Preliminary Study

Based on the results of the preliminary study that has been conducted, several problems have been identified with regards to the conduct of the learning process in the school. One of the problems is that the learning process still relies on the use of lecture method and the use of this method has caused the students to be passive and to be inclined as the retriever of the knowledge. In addition, another problem that has been found is that the functional academic teaching materials have not been found in the field. Specifically, the data from the conduct of the preliminary study in the Yaketunis Type A Special School show that the teaching materials have not been well summarized. In the same time, it is also found that in general the curriculum has been modified from the one that has been implemented in the general school.

Then, the results of the study with the teachers from the Special School show that the teachers still have difficulties in developing the students' capability with regards to their know- ledge and skills in using the functional academic learning materials in the daily life. The data that have been retrieved from the library study toward the Core Competence and the Basic Competence, the 2013 Curriculum Textbook for the Type A Students with Impairment and other literatures in relation to the implementation of the functional academic learning materials, it is found that: (1) the materials for the functional academic implementation have not been apparent but yet there have been incorporations on several subjects, for example: introduction to money; (2) the use of the money has been adjusted to the needs of the students with visual impairment in the daily life; and (3) there have been attentions on the skills in terms of adaptive behaviours among the students with visual impairment as they use their money.

The teachers expect the presence of handout or textbook on the summary of functional academic teaching materials that might be easily understood. The presence of such handout or textbook is expected in both the caution form and the Braille form so that the teachers with visual impairment might also utilize them in the learning process practically. Then, the ease to understand the coverage of the functional academic teaching materials might be seen from the functional, reading, writing and counting skills. Furthermore, in this regard, the teachers suggest that the composition of the textbooks might be joined with the learning media; in other words, the brief and simple textbook with lots of materials and completed with relevant illustration should be afforded. In addition, the content of the textbook that will be composed should emphasize more on the teaching method and stages in accordance to the Contextual Teaching and Learning (CTL) Model. The explanation of each learning stage is expected to presented in details and clearly altogether with real examples so that the teachers will be more facilitated in understanding the functional academic learning process. In the same time, the teachers also expect the presence of general fundamental concepts within the functional academic teaching materials prior to the conduct of the learning process. Eventually, there should be a kind of display about how to internalize concepts since the beginning of the learning process because the students with completely visual impairment demand more guidance due to their orientation and mobilization.

Departing from the above elaboration, the conclusion that might be drawn is that the special teachers for the students with visual impairment demand a presence of more ordered and syste- 
Jurnal Prima Edukasia, 7 (2), 2019 - 187

Sayidatul Maslahah, Ishartiwi Ishartiwi, Mumpuniarti Mumpuniarti, Yeni Irma Normawati

matic functional academic teaching materials in accordance to the process in the learning stages of the contextual learning model syntaxes.

Design

This stage consists of two parts namely product design and product manufacture. The design and the manufacture of the product is performed based on the needs in the field, namely the needs toward the teaching materials that might be utilized in the functional academic learning process. Specifically, the teaching materials are expected to be utilized in the functional academic learning process that covers the functional reading, writing and counting skills. Then, within this stage the very first step that should be done has been making the storyboard. Storyboard refers to the brief summary that descriptively contains the path that will exist within the learning product, starting from the preliminary description and the concept introduction until the assessment. From the results of the product design activities, several pages have been found and these pages consist of competence page, material page, evaluation page, direction page and profile of developers' page.

Then, the components of the teacher book cover the student activities and the explanation on the Contextual Teaching and Learning (CTL) Model. The teaching materials in the so-called teacher book consist of several main parts namely: (1) Cover, which contains the title of the teaching materials, the name of the authors and the institution of the authors; (2) Book Identity; (3) Foreword, which contains the words of gratitude from and the intention of the teaching material composition by the researchers as the authors; (4) Glossary, which contains important terms; (5) Introduction, which contains brief description on the concept of functional academic learning process and the objective of the textbook composition; (6) Learning requirements, which contain the competence that should be mastered and internalized by the teachers as the users of the teaching materials; (7) earning objectives, which contain the competence that will be the learning output and the indicators of the learning process achievement; (8) Direction, which contains guidelines for the teachers in understanding and utilizing the material contents well; (9) Teaching material content map, which contains the scope and the coverage of the materials that have been developed in the teaching materials; and (10) Content, which is divided into several parts namely: (a) Contextual teaching and learning; (b)
Functional academic; (c) Students with visual impairment; (d) Learning steps; (e) Lesson plans and assessment; (f) List of references, which contain the literature sources that the authors have used; (g) Author and reviewer identity, which contain the name and the institution origin of both the author and the reviewers complete with their picture.

\section{Development}

After the media has been completely designed, the media should be sent to the stage of product validation and test. The objective of this stage is to identify and fix the errors that have been found in the learning media that has been developed. Then, this stage consists of several components and these components might be elaborated as follows.

\section{Instrument Validation}

The instrument that has been designed should be validated in order to define whether the instrument has been fit or not for gathering the research data. The validation is performed by the expert lecturer majoring in the domain of the students with impairment education.

\section{Expert Validation}

The preliminary product in the form of teacher's guidebook is validated by the media expert and the material expert. The media that has been designed is validated in order to identify the media fitness for implementation. Then, the media validation is performed by the expert lecturer majoring in the learning media from the Department of Education Technology, Universitas Negeri Yogyakarta.

\section{Media Expert Assessment}

\section{Description on the Results of the Media Expert Assessment}

The data from the assessment results by the first media expert and the second media expert in the first stage cover the aspects of text display, colour display, picture display, layout display, physical display and design components. The assessment results are described in Table 1, Table 3, Table 3, and Table 4.

Based on the data from the assessment by the first media expert and the second media expert in the first stage (Table 1), in overall the mean score of the media is 3.60 with the "Very Good" category. The implication of this result is that the media has been fit for implementation. 
Jurnal Prima Edukasia, 7 (2), 2019 - 188

Sayidatul Maslahah, Ishartiwi Ishartiwi, Mumpuniarti Mumpuniarti, Yeni Irma Normawati

Based on the data from the assessment by the first media expert and the second media expert in the second stage (Table 2), in overall the mean score of the media is 3.80 with the "Very Good" category. The implication of this result is that the media has been fit for implementation.

Material Expert Assessment

\section{Description on the Results of the Material Expert Assessment}

In the meantime, the results of the material validation by the expert lecturer majoring in the Students with Impairment Education and the expert lecturer majoring in the Students with Visual impairment from the Yogyakarta State University, the mean score of the material is 3.65 with the "Very Good" category. In other words, it might be implied that the media has been fit for implementation.
Based on the data from the first media expert and the second material expert in the stage 1 (Table 3), in overall the mean score is 3.65 with the "Very Good" category. Therefore, it might be concluded that the media has been fit for implementation.

Based on the data from the assessment by the first expert media and the second media expert in the stage 2 (Table 4), in overall the mean score of the media is 3.80 with the "Very Good" category. Therefore, it might be concluded that the media has been fit for implementation.

Test

\section{Preliminary Test Data}

The product in the form of the functional academic teaching materials has been fit for implementation and therefore the product the should undergo the product test in the Yaketunis Type A Special School.

Table 1. Results of Expert Validation in the First Stage

\begin{tabular}{clcccc}
\hline \multirow{2}{*}{ No. Aspects } & \multicolumn{1}{c}{$\sum$ Media Expert } & \multirow{2}{*}{ Mean Score } & \multirow{2}{*}{ Category } \\
\cline { 3 - 4 } & \multicolumn{1}{c}{ I } & II & & Very Good \\
1. & Language Appropriateness & 3.60 & 3.50 & 3.525 & Very Good \\
2. & Graphic & 3.90 & 3.80 & 3.850 & Very Good \\
3. & Teaching Material Quality and Size & 3.50 & 3.70 & 3.600 & Very Good \\
4. & Display Fitness & 3.70 & 3.50 & 3.600 & Very Good \\
\hline
\end{tabular}

Table 2. Results of Expert Validation in Stage 2

\begin{tabular}{|c|c|c|c|c|c|}
\hline \multirow{2}{*}{ No. } & \multirow{2}{*}{ Aspects } & \multicolumn{2}{|c|}{$\sum$ Media Expert } & \multirow{2}{*}{ Mean Score } & \multirow{2}{*}{ Category } \\
\hline & & I & II & & \\
\hline 1. & Language Appropriateness & 3.70 & 3.75 & 3.725 & Very Good \\
\hline 2. & Graphic & 4.00 & 4.00 & 4.000 & Very Good \\
\hline 3. & Teaching Material Quality and Size & 3.60 & 3.80 & 3.700 & Very Good \\
\hline 4. & Display Fitness & 3.80 & 3.70 & 3.750 & Very Good \\
\hline & Mean Score & & & 3.80 & Very Good \\
\hline
\end{tabular}

Table 3. Results Material Expert Validation in Stage 1

\begin{tabular}{|c|c|c|c|c|c|}
\hline \multirow{2}{*}{ No. } & \multirow{2}{*}{ Aspects } & \multicolumn{2}{|c|}{$\sum$ Material Expert } & \multirow{2}{*}{ Mean Score } & \multirow{2}{*}{ Category } \\
\hline & & $\mathrm{I}$ & II & & \\
\hline 1. & Material Display & 3.40 & 3.60 & 3.50 & Very Good \\
\hline 2. & Material Completeness & 3.50 & 3.60 & 3.55 & Very Good \\
\hline 3. & Material Accuracy & 3.60 & 3.70 & 3.65 & Very Good \\
\hline 4. & Language Accuracy & 3.90 & 3.80 & 3.85 & Very Good \\
\hline & Mean Score & & & 3.65 & Very Good \\
\hline
\end{tabular}

Table 4. Results of Material Expert Validation in Stage 2

\begin{tabular}{|c|c|c|c|c|c|}
\hline \multirow{2}{*}{ No. } & \multirow[b]{2}{*}{ Aspects } & \multicolumn{2}{|c|}{$\sum$ Material Expert } & \multirow{2}{*}{ Mean Score } & \multirow[b]{2}{*}{ Category } \\
\hline & & $\mathrm{I}$ & II & & \\
\hline 1. & Material Display & 3.60 & 3.80 & 3.700 & Very Good \\
\hline 2. & Material Completeness & 3.65 & 3.75 & 3.700 & Very Good \\
\hline 3. & Material Accuracy & 3.80 & 3.85 & 3.825 & Very Good \\
\hline 4. & Language Accuracy & 3.90 & 3.90 & 3.900 & Very Good \\
\hline & Mean Score & & & 3.80 & Very Good \\
\hline
\end{tabular}


Jurnal Prima Edukasia, 7 (2), 2019 - 189

Sayidatul Maslahah, Ishartiwi Ishartiwi, Mumpuniarti Mumpuniarti, Yeni Irma Normawati

The subjects in the product test are three teachers namely $\mathrm{Y}, \mathrm{W}$ and $\mathrm{D}$. The selection of the teachers is based on the fact that they used to teach the fundamental knowledge to the students with visual impairment namely reading, writing and counting. Then, the product test is conducted as part of consideration for the further revision based on the response questionnaire and the teacher feedback. The product test itself is conducted by delivering the product to the teachers so that the teachers might examine it and later assess it by completing the questionnaire from the aspect of layout fitness, language, display and material accuracy. The teachers observe carefully the teaching materials from the Cover to the Table of Contents, Chapter 1, Chapter 2, Chapter 3, Chapter 4, Chapter 5 and Chapter 6 and eventually to Assessment. The overall results of the product tst show that the product has been good. In details, the results of the preliminary field test might be consulted in Table 5 .

Based on the preliminary field test data (Table 5) with the three teachers, the overall assessment shows that the mean score of the media has been 3.75 with the category "Very Good." Therefore, it might be concluded that the media has been fit for implementation. However, product revision should be performed in order to improve the media in accordance to the feedback and the suggestions that the three teachers have provided based on the preliminary field test results. Despite the preliminary field test results, it is apparent that there is not any component that should be revised based on the teacher assessment. As a result, the preliminary field test might proceed to the operational field test.

\section{Main Field Test/Operational Field Test}

The main or the operational field test is conducted by involving six teachers who belong to the Special School for the Students with Visual impairment. The operational field test is conducted by delivering the product to the teachers so that the teachers might examine the product carefully. After the teachers have examined the product carefully, the teachers will assess the product by completing the questionnaire from all aspects. The assessment results from the main or the operational field test might be consulted in Table 6.

Based on the data in Table 6 , the overall assessment by the teachers in the main or the operational field test show that the mean score of the media is 3.70 with the "Very Good" category. Therefore, it might be concluded that the media has been fit for implementation.

Table 5. Preliminary Field Test

\begin{tabular}{|c|c|c|c|c|c|c|}
\hline \multirow{2}{*}{ No. } & \multirow{2}{*}{ Assessment Elements } & \multicolumn{3}{|c|}{$\sum$ Score } & \multirow{2}{*}{ Mean Score } & \multirow{2}{*}{ Category } \\
\hline & & $\mathrm{I}$ & II & III & & \\
\hline 1. & Material Display Clarity & 3.70 & 3.70 & 3.60 & 3.675 & Very Good \\
\hline 2. & Material Completeness & 3.50 & 3.70 & 3.60 & 3.600 & Very Good \\
\hline 3. & Material Accuracy & 3.70 & 3.80 & 3.85 & 3.800 & Very Good \\
\hline 4. & Language Accuracy & 3.80 & 3.90 & 3.90 & 3.875 & Very Good \\
\hline 5. & Text Readability & 3.90 & 3.90 & 3.90 & 3.900 & Very Good \\
\hline 6. & Picture Clarity & 3.90 & 3.80 & 3.70 & 3.800 & Very Good \\
\hline 7. & Color Use Attraction & 3.80 & 3.80 & 3.70 & 3.725 & Very Good \\
\hline 8. & Page Design Attraction & 3.90 & 3.90 & 3.90 & 3.900 & Very Good \\
\hline 9. & Teaching Materials Ease of Use & 3.60 & 3.70 & 3.70 & 3.625 & Very Good \\
\hline 10. & Assessment and Evaluation Clarity & 3.40 & 3.50 & 3.60 & 3.500 & Very Good \\
\hline & Mean Score & & & 3.75 & & Very Good \\
\hline
\end{tabular}

Table 6. Results of the Main or the Operational Field Test

\begin{tabular}{clccccccc}
\hline \multirow{2}{*}{ No. } & \multicolumn{2}{c}{ Assessment Elements } & \multicolumn{4}{c}{$\sum$ Score } & \multirow{2}{*}{ Category } \\
\cline { 3 - 7 } & & I & II & III & IV & V & VI & \\
\hline 1. & Material Display Clarity & 3.60 & 3.50 & 3.40 & 3.60 & 3.80 & 3.70 & Very Good \\
2. & Material Completeness & 3.80 & 3.50 & 3.40 & 3.60 & 3.70 & 3.70 & Very Good \\
3. & Material Accuracy & 3.40 & 3.50 & 3.30 & 3.80 & 3.60 & 3.60 & Very Good \\
4. & Language Accuracy & 3.50 & 3.70 & 3.90 & 3.60 & 3.60 & 3.70 & Very Good \\
5. & Text Readability & 3.90 & 3.80 & 3.90 & 3.50 & 3.40 & 3.70 & Very Good \\
6. & Picture Clarity & 3.80 & 3.90 & 3.90 & 3.80 & 3.70 & 3.80 & Very Good \\
7. & Color Use Attraction & 3.80 & 3.50 & 3.40 & 3.30 & 3.60 & 3.80 & Very Good \\
8. & Page Design Attraction & 3.90 & 3.40 & 3.40 & 3.80 & 3.90 & 3.90 & Very Good \\
9. & Teaching Materials Ease of Use & 3.60 & 3.80 & 3.70 & 3.80 & 3.90 & 3.80 & Very Good \\
10. & Assessment and Evaluation Clarity & 3.50 & 3.30 & 3.20 & 3.30 & 3.30 & 3.20 & Very Good \\
\hline
\end{tabular}


Jurnal Prima Edukasia, 7 (2), 2019 - 190

Sayidatul Maslahah, Ishartiwi Ishartiwi, Mumpuniarti Mumpuniarti, Yeni Irma Normawati

\section{Discussions}

The research and development initiative has resulted in a product takes the form of very good functional academic teaching materials with "Fit for Implementation" category for the special teachers of students with visual impairment in Special School Type A. The process of composing the teaching materials has gone through 9 stages of research that has been based on the Borg \& Gall model (Gall et al., 2003). The very first stage, namely Preliminary Study, is conducted in order to analyse the potentials and the problems that might be found in the field; then, the preliminary study is proceeded by performing preliminary observation and interview with the teachers in the Yaketunis Type A Special School. Based on the results of the preliminary observation toward several aspects, it might be concluded that the functional academic curriculum that has been found in the field is a result of modification from the regular curriculum. Consequently, the teachers have difficulties in explaining the materials to the students. Not to mention, the teaching materials that have been found in the field do not entail any specific method of explanation with regards to the functional academic content; as a result, the teachers do not understand how teach the functional reading, writing and counting skills systematically. The term functional academic refers to the coverage of a learning process in the form of review toward symbols or codes that have been used by an individual in adapting himself or herself to the surrounding environment (Bouck \& Joshi, 2012; Mumpuniarti \& Pujaningsih, 2016, p. 98). There are three parts that become the coverage of the functional academic content. The first part is functional reading skills, which cover the activities of reading the symbols that have been found in the surrounding environment. Then, the second part is functional writing skills, which cover the activities of writing aspects that might be directly implemented in the daily life context. Last but not the least, the third part is functional counting skills, which cover the activities of utilizing the realistic mathematical learning process. The realistic mathematical learning process utilizes the reality and the environment that the students understand in order to facilitate the mathematical learning process in terms of concrete aspects. Teaching and learning Realistic Mathematics keeps possession of certain criteria especially with regards to the students' experiences in the daily life. In other words, through
Realistic Mathematics the subject is applied into the problem-solving efforts for the daily life context (Yuanita et al., 2018).

All coverages in the domain of functional academc materials have been taught to the students with visual and intellectual impairment by paying attention to their learning needs and characteristics. The reason is that these students demand concrete and functional learning process (Salekin et al., 2010, p. 98). Therefore, what the students with visual impairment perform in order to attain information might be emphasized on the aspects of visual and tactile sense (Hötting \& Röder, 2009; Solso et al., 2008; Subagya, 2019). Furthermore, the learning process for the students with visual impairment demands learning model, teaching method, learning process, learning material adaptation and learning environment (Bandura \& Walters, 1977). Hence, the teachers might modify the learning process by creating classroom activities that might be set into the daily situation context in the real life (Hallahan et al., 2018).

Specific to the context of the study, the product that has been developed is the functional academic teaching materials that prioritize the user characteristics, the competence objectives, the material coverage, the assessment tool and the assessment. These aspects are referred by the researcher as an anticipative step toward the development of the contents for the teaching materials. Then, within the conduct of the study, there has been an analysis toward the needs of the special teachers within the learning process in accordance to the basic competence of the students with visual impairment. The basic competence objective and the material coverage are composed are also inserted in the teaching material content so that it might be easier for the students to learn them. Furthermore, the teaching materials are also equipped with the measurement assessment for each grade in the form of written test. This initiative is in accordance to the argument by Susilana and Riyana (2008), who argue that teaching materials should be designed in a systematic and structured manner so that the teaching materials might be easy to learn and the truth of the concepts in a science might be establish in a complete state of integrity.

In addition, the teachers demand the availability of handouts or textbooks about the functional academic learning process that might learned easily especially with regards to the ease of learning the reading, writing and counting manner. In the same time, the teachers also 
Jurnal Prima Edukasia, 7 (2), 2019 - 191

Sayidatul Maslahah, Ishartiwi Ishartiwi, Mumpuniarti Mumpuniarti, Yeni Irma Normawati

suggest the availability of textbooks that might be utilized for understanding the brief procedures within the composition of a textbook with indepth materials and supporting illustrations. The content of such textbook is expected to provide the display on how to read, how to write and how to apply mathematical skills through a sequential manner. The explanation of each code should be entailed with an example of reading and writing skills so that the teachers might be facilitated in explaining the functional academic learning materials. Despite the lengthy elaboration, such learning materials will be meaningless if the quality of the learning materials is poor. Therefore, the development of such learning materials should meet certain criteria. According to (Widodo \& Jasmadi, 2008, pp. 40-48), the criteria of good learning materials are namely: (1) fulfilling the content fitness; (2) fulfilling the language fitness; (3) fulfilling the presentation fitness; and (4) fulfilling the graphic fitness.

Based on the results of the interview with the teachers, the teachers demand the availability of teaching materials that have clear language use, that are communicative, that have in-depth knowledge and that are systematic. The coverage of the content within such learning materials should be adjusted to the conditions of the students who will be engaged in the learning process. in addition, the learning materials should be continuous from one topic to another. This elaboration is in accordance to argument by (Dar, 2012; Ouyang \& Stanley, 2014; Suparman, 2012; Supriyadi, 2013), which altogether state that good learning materials should have the following characteristics: (1) contain clear instructional objectives; (2) have contents that are relevant to the needs of the students who will use the learning materials; (3) have content that are relevant in accordance to the discipline; (4) have contents that are up to date in terms of both theories and examples; (5) have systematic, logical and understandable explanation; (6) use various methods and media; (7) use original quotations; (8) have supports from the results of relevant studies; (9) have various exercises in accordance to the instructional achievement; and (10) have valid and reliable test.

The criteria that have been demanded by the teachers in the Special School are also in accordance to the argument by Harjanto (2010, p. 222), who state that the criteria of good instructional objective are the ones that follow this principle: the selected learning materials are intended to achieve the objectives that have been defined. In addition, in order that the learning materials are elaborated well, there should be close links between the specification of the instructional objectives and the specification of the learning materials so that the elaboration process might be observed and measured. Not to mention, the learning materials should be relevant to the students' needs as well; every learning material that will be delivered should be in accordance to the efforts of developing the students into a complete personality. Then, for the sake of the concordance with the society, the materials that will be selected should assist the students in attaining the meaningful educative experience for their development so that the students become individuals who are able to adapt themselves easily. Therefore, the learning materials should contain ethical aspects, should be composes in systematic and logical order and coverage, should have orders in terms of consideration toward the factors of the students' psychological development and should be derived from the standard textbooks, expert teachers and society.

Furthermore, the teaching materials prioritize the learning aspects for the students with visual impairment namely the visual sense and the tactile sense. Consequently, the overall criteria in the teaching materials compo-sition should be in accordance to the learning needs of the students with visual impairment. Then, the learning aspects of the students with visual impairment consist of three different environments namely visual environment, auditory environment and tactile environment. Therefore, it is expected that the development of the teaching materials should follow this principle so that the learning results that the students with visual impairment might achieve can be maximum (Sunanto, 2005).

The use of the human senses other than the visual sense might be maximized. For example, the use of auditory sense might be maximized by having good discussions and communications. Through the good discussions and communications, the students might attain experiences that can be associated to the learning materials. As another example, the tactile sense might also be maximized by using the concrete objects within the learning media (Saputri \& Wangid, 2013).

The above explanation suits into the argument by (Hallahan et al., 2018, p. 117), who state that the learning process for the students with visual impairment who have intellectual obstacles should be performed by using the instruction in real-life setting with real materials. 
Jurnal Prima Edukasia, 7 (2), 2019 - 192

Sayidatul Maslahah, Ishartiwi Ishartiwi, Mumpuniarti Mumpuniarti, Yeni Irma Normawati

The teachers might compose learning activities that are set in the daily life context; for instance, the teachers might teach the students about how to do the shopping activities. In this regard, the contribution of the functional academic approach is found in the mediation on the use of the symbols or the codes toward the phenomena in the surrounding environment. In the same time, the role that has been found in the functional academic approach is also in accordance to its contribution in the daily life. (Johnson, 2002, p. 24) states that the functional academic learning process enables the students to link the content of the materials to the context of the daily life so that the learning process will be more meaningful.

The teaching materials that have been developed in the study take the form of teacher's guidebook for conducting the functional academic learning process that might be independently used by the teachers. The teacher's guidebook that has been developed is based on the Contextual Teaching and Learning (CTL) Model; consequently, there will be provisions on the learning stages that have been related to the daily activities. The Contextual Teaching and Learning (CTL)-based functional academic learning process implements certain learning syntaxes. The CTL Model itself refers to the educational process that encourage the students to be able to contemplate on the academic learning with the content in the form of the daily life context, namely the personal, social and cultural life context. In addition, the CTL Model also refers to the model that provides the students with the opportunity to try, perform and experience their own learning situations (Sihotang \& Sibuea, 2015).

The syntaxes of the CTL-Model involve seven main learning components namely: (1) constructivism; (2) inquiry; (3) questioning; (4) learning community; (5) modelling; (6) reflection; and (7) authentic assessment. Constructivism becomes the reasoning foundation or the philosophy of the contextual approach. Constructivism, in the same time, also refers to the process of establishing new knowledge within the cognitive structures of the students based on their experiences. With regards to constructivism, the contextual approach basically emphasizes the importance for the students to establish their own knowledge through the active involvement within the teaching-learning process (Trianto, 2010, p. 111). Then, the second component is inquiry. Inquiry refers to the learning process that has been based on the invention and the discovery through the systematic thinking process (Sanjaya, 2008). Next, the third component is questioning. With regards to questioning, learning process is essentially questioning and answering questions. Therefore, questioning might be considered as a reflection on the curiosity of each individual whereas answering questions reflects the capability of an individual in performing thinking process (Sanjaya, 2008, p. 266).

Furthermore, the fourth component is learning community. The concept of CTL-based learning process suggests that the results of the learning process should be attained from cooperation with other individuals (Sanjaya, 2008, p. 267). Afterward, the fifth component is modelling. Modelling refers to the process of displaying an example so that individuals might think, learn and work with regards to their necessary role in the implementation of the CTL-Model. Subsequently, the sixth component is reflection. According to Sanjaya (2008), within reflection the experiences that have been learned are precipitated in the brain by reordering the learning events or experiences that have been attained. Last but not the least, the seventh component is authentic assessment. The authentic assessment in CTL deals with the activities of assessing the students' knowledge and skills. The students' knowledge and skills should be assessed in order to improve their skills in living their daily life. In addition to the overall elaboration of the seven components, within each component or learning stage the teaching methods and also the real examples are provided with regards to the daily life so that the teachers might be facilitated in performing the learning process.

The process of developing the teaching materials has utilized the design software and the word-processing software namely Corel Draw and Microsoft Word. The Corel Draw has been utilized for designing the cover and the content of the book. On the other hand, the Microsoft Word has been utilized for explaining the concept, the learning stages and the evaluation of the functional academic learning process. The development of the teaching materials itself refers to the curriculum analysis that has been performed in the special elementary schools for the students with visual impairment by the researcher and the suggestions that have been provided by the functional academic material expert.

The teacher's guidebook consists of the foundations for the guidebook development and the stages that should be performed in the contextual-based functional academic learning 
Jurnal Prima Edukasia, 7 (2), 2019 - 193

Sayidatul Maslahah, Ishartiwi Ishartiwi, Mumpuniarti Mumpuniarti, Yeni Irma Normawati

activities. In addition, the teacher's guidebook also contains contextual use namely the problems that might be linked to the real-life context such as market day, transactional cash use and alike. The core of this learning process also emphasizes the four fundamental aspects in the functional academic learning process namely functional reading, functional writing, functional mathematics and mathematical application in the reallife context.

Due to the above situation, the Contextual Teaching and Learning (CTL) Model has been adopted in order to bridge the abstract matters to the concrete matters (the objects in the real-life context). In addition, the CTL Model has been adopted in order to bridge the students' construction (the efforts to solve a problem in order to discover the learning results), the students' interactivity (the students' activities) and the intertwining topics (the link from one material to another). Therefore, the teacher's guidebook contains learning stages that have been based on the market day-concept and the Contextual Teaching and Learning (CTL)-Model. Every learning activity within the teacher's guidebook also contains necessary tools and steps for initiating the learning process.

Based on the results of the potential and problem analysis, the solution that has been found is in the form of functional academic teaching material development. With regards to the functional academic teaching material development, the data that have been relevant to the content of the teaching materials should be gathered. Then, the functional academic teaching materials have been developed and have been designed in order to compose the preliminary product. The development and the design of the preliminary product is adjusted to the learning aspects and needs of the students with visual impairment so that the prototype of the product is ready for validation. After the development and the design of the preliminary product has been completed, the preliminary product should be validated by the media expert, namely a lecturer from the Department of Educational Technology, and the material expert, namely a lecturer from the Department of Special Education.

The results of the validation by both the material expert and the media expert are provided in the form of fitness assessment and feedback toward the product namely the functional academic teaching materials and serve as the preliminary step in revision so that the functional academic teaching materials might be analysed in terms of material and media. The results of the validation show that the functional academic teaching materials show that the functional academic teaching materials have been fit for implementation. However, there are still several revisions that have to be pursued and most of these revisions are found in the activities of the material validation and related to the language use namely: (1) inappropriate diction; and (2) indepth materials. The depth of the functional academic teaching materials should be detailed further into functional reading, functional writing and functional counting.

On the contrary, the results of the fitness test from the media expert show that the functional academic teaching materials have been fit for implementation with several revisions. Then, the suggestions and the feedback that have been provided by the media expert are related to the following aspects: (1) space layout; (2) background colour selection; and (3) font selection. Specific to the font selection, the font selection should be more general because the lower part of the letter " $t$ " has been lost and consequently the letter "t" might be considered as the symbol "+." Departing from the revisions, the assessment proceeds to the second validation stage so that the functional academic teaching materials might be fit for implementation. The fitness of the functional academic teaching materials has also been confirmed by the results of an test with three subjects and another test with five subjects. The results of both tests show that the functional academic teaching materials have been fit for implementation. There is any single revision that has been found from the two tests and the response from the teachers show that the functional academic teaching materials have been very helpful for teaching the students with visual impairment.

The functional academic teaching materials have been designed based on the criteria of sufficient teaching materials which cover the material aspects and the media aspects. The materials that have been inserted into the functional academic teaching materials are already in accordance to the modification of the curriculum that the teachers have implemented. These materials have also been clearly displayed by using the simple terms and language so that the teachers might easily utilize the functional academic teaching materials. Not to mention, the materials that have been displayed are also systematic, related to the daily-life context, as completely 
Jurnal Prima Edukasia, 7 (2), 2019 - 194

Sayidatul Maslahah, Ishartiwi Ishartiwi, Mumpuniarti Mumpuniarti, Yeni Irma Normawati

designed as possible and based on the Contextual Teaching and Learning (CTL)-Model.

From the media aspects, the functional academic teaching materials that have been composed in general belong to the "Fit" category because the materials contain complete teaching material components and are designed based on the Contextual Teaching and Learning (CTL) Model. The syntaxes of the CTL-Model itself consists of seven main learning components namely constructivism, inquiry, questioning, learning community, modelling, reflection and authentic assessment. In overall, based on the test stages and results in the Yaketunis Type A Special School, it might be concluded that the functional academic teaching materials, especially for the functional reading, writing and calculating activities, for the students with visual impairment have been fit.

\section{Conclusions}

Based on the results of and the discussions within the study, several conclusions might be drawn. First, the product that has been composed in the study is the functional academic teaching materials for the students with visual impairment. Second, the data from the assessment results by the media expert and the material expert as well as the data from the test results by the teacher show that the product has been fit for implementation in the school. The aspects that have been assessed and tested are the material/ content aspects, the presentation aspects, the language aspects and the graphic aspects. The mean score by the media expert, namely 3.65 , and by the material expert, namely 3.80 , confirms that the functional academic teaching materials have been fit and very good for implementation by the special teachers. In the same time, the mean score of the response within the test stage, namely 3.70, also confirms that the Contextual Teaching and Learning (CTL)-based functional academic teaching materials have been fit for implementation. In sum, it is clear that the Contextual Teaching and Learning (CTL)-based functional academic teaching materials have been fit for serving as the functional academic teaching materials for the students especially with regards to the functional reading, writing and counting activities for the students with visual impairment.

\section{References}

Bandura, A., \& Walters, R. H. (1977). Social learning theory. Prentice-hall.

Bobzien, J. L. (2014). Academic or functional life skills? using behaviors associated with happiness to guide instruction for students with profound/multiple disabilities. Education Research International, 2014, $1-12$. https://doi.org/10.1155/2014/710816

Bouck, E. C., \& Joshi, G. (2012). Functional curriculum and students with mild intellectual disability: Exploring postschool outcomes through the NLTS2. Education and Training in Autism and Developmental Disabilities, 47(2), 139153.

Chanda, D. H., Phiri, S. N. A., Nkosha, D. C., \& Tambulukani, G. (2000). Teaching and learning materials analysis and development in basic education. UNESCO Basic Education Capacity Building Project: Training Kits for Local ....

Dar, F. (2012). Textbook materials and their successful application in the classroom: Implications for language development. Journal of Educational and Instructional Studies in the World, 2(4), 109-114.

Dick, W., Carey, L., \& Carey, J. O. (2009). The systematic design of instruction (8th ed.). Pearson.

Fauziyah, L., \& Jailani, J. (2014). Pengembangan perangkat pembelajaran matematika yang menunjang pendidikan karakter siswa kelas IV sekolah dasar. Jurnal Prima Edukasia, 2(2), 149-163. https://doi.org/10.21831/jpe.v2i2.2715

Gall, M. D., Gall, J. P., Borg, W. R. D., \& Gall, J. P. (2003). Educational research: An introduction (7th ed.). Pearson Education Inc.

Giesen, J. M., Cavenaugh, B. S., \& McDonnall, M. C. (2012). Academic supports, cognitive disability and mathematics acheivement for visually imparied youth: A multilevel modeling approach. International Journal of Special Education, 27(1), 17-26.

Hallahan, D. P., Kauffman, J. M., \& Pullen, P. C. (2018). Exceptional learners: Introduction to special education (9th ed.). Pearson Education.

Hamalik, O. (2009). Proses belajar mengajar. Bumi Aksara.

Harjanto, H. (2010). Perencanaan pengajaran. Rineka Cipta. 
Jurnal Prima Edukasia, 7 (2), 2019 - 195

Sayidatul Maslahah, Ishartiwi Ishartiwi, Mumpuniarti Mumpuniarti, Yeni Irma Normawati

Hartoyo, H. (2009). Penerapan model pembelajaran kontekstual berbasis kompetensi untuk meningkatkan efektivitas pembelajaran. Jurnal Kependidikan: Penelitian Inovasi Pembelajaran, 39(1), 67-78. https://doi.org/10.21831/jk.v39i1.233

Hauser, S., Levack, N., \& Newton, L. (1999). Functional academics - A curriculum for students with visual impairments. TSBVI Logo Texas School for the Blind and Visually Impaired.

Hötting, K., \& Röder, B. (2009). Auditory and auditory-tactile processing in congenitally blind humans. Hearing Research, 258(12), 165-174. https://doi.org/10.1016/j.heares.2009.07.0 12

Indaryati, I., \& Jailani, J. (2015). Pengembangan media komik pembelajaran matematika meningkatkan motivasi dan prestasi belajar siswa kelas V. Jurnal Prima Edukasia, $\quad 3(1), \quad$ 84-96. https://doi.org/10.21831/jpe.v3i1.4067

Johnson, E. B. (2002). Contextual teaching and learning: What it is and why it's here to stay. Corwin Press.

Kauffman, J. M., \& Hallahan, D. P. (2011). Handbook of special education. Routledge.

Light, G., Calkins, S., \& Cox, R. (2009). Learning and teaching in higher education: The reflective professional. Sage.

Miles, M. B., Huberman, A. M., \& Saldaña, J. (2014). Qualitative data analysis: A methods sourcebook. Sage.

Mumpuniarti, M., \& Pujaningsih, P. (2016). Pembelajaran akademik fungsional dalam konteks pendidikan khusus orientasi budaya. UNY Press.

Ouyang, J. R., \& Stanley, N. (2014). Theories and research in educational technology and distance learning instruction through Blackboard. Universal Journal of Educational Research, 2(2), 161-172.

Piaget, J., \& Inhelder, B. (2010). Psikologi anak (M. Jannah (trans.)). Pustaka Pelajar.

Prasetyo, A. D. (2017). Pengembangan multimedia pembelajaran interaktif mata pelajaran IPA pokok bahasan bumi dan alam semesta kelas VI SD Negeri Ngringin
Depok Sleman. E-Jurnal Skripsi Program Studi Teknologi Pendidikan, 6(7), 684697.

http://journal.student.uny.ac.id/ojs/ojs/ind ex.php/fiptp/article/view/8410

Undang-Undang Republik Indonesia nomor 20 tahun 2003 tentang sistem pendidikan nasional, Pub. L. No. 20, Undang-Undang Republik Indonesia 26 (2003).

Purnomo, H., \& Wilujeng, I. (2016). Pengembangan bahan ajar dan instrumen penilaian IPA tema indahnya negeriku penyempurnaan buku guru dan siswa kurikulum 2013. Jurnal Prima Edukasia, 4(1), 67-78. https://doi.org/10.21831/jpe.v4i1.7697

Rudiyati, S. (2002). Pendidikan anak tunanetra. FIP UNY.

Sagala, S. (2009). Konsep dan makna pembelajaran untuk membantu memecahkan problematika belajar dan mengajar. Alfabeta.

Salekin, K. L., Olley, J. G., \& Hedge, K. A. (2010). Offenders with intellectual disability: Characteristics, prevalence, and issues in forensic assessment. Journal of Mental Health Research in Intellectual Disabilities, 3(2), 97-116. https://doi.org/10.1080/193158610036957 69

Sanjaya, W. (2008). Strategi pembelajaran berorientasi standar proses pendidikan. Prenada Media. https://doi.org/2008

Saputri, A. E., \& Wangid, M. N. (2013). Pembelajaran sains SD untuk siswa tunanetra di SLB-A Yaketunis. Jurnal Prima Edukasia, 1(2), 124-134. https://doi.org/10.21831/jpe.v1i2.2630

Sari, I. P., \& Syamsi, K. (2015). Pengembangan buku pelajaran tematik-integratif berbasis nilai karakter disiplin dan tanggung jawab di sekolah dasar. Jurnal Prima Edukasia, $3(1)$, 73-83. https://doi.org/10.21831/JPE.V3I1.4070

Sihotang, C., \& Sibuea, A. M. (2015). Pengembangan buku ajar berbasis kontekstual dengan tema "sehat itu penting." Jurnal Teknologi Informasi \& Komunikasi Dalam Pendidikan, 2(2).

Smith, D. D., \& Tyler, N. C. (2010). Introduction to special education: Making a difference. Merrill/Pearson Education. 
Jurnal Prima Edukasia, 7 (2), 2019 - 196

Sayidatul Maslahah, Ishartiwi Ishartiwi, Mumpuniarti Mumpuniarti, Yeni Irma Normawati

Solso, R. L., Maclin, O. H., \& Maclin, M. K. (2008). Psikologi kognitif. Erlangga.

Subagya, S. (2019). Pengembangan buku siswa audio taktual (BSAT) matematika SMP/sederajat untuk siswa tunanetra. Universitas Negeri Yogyakarta.

Sunanto, J. (2005). Mengembangkan potensi anak berkelainan penglihatan. Departemen Pendidikan Nasional Republik Indonesia.

Suparman, M. A. (2012). Desain instruksional modern: panduan para pengajar \& inovator pendidikan (N. I. Sallama (ed.)). Erlangga.

Supriyadi, S. (2013). Developing teaching materials of writing scientific paper using constructvision approach. Journal of Education and Practice, 4(24), 34-42.

Susilana, R., \& Riyana, C. (2008). Media pembelajaran: hakikat, pengembangan, pemanfaatan, dan penilaian. CV. Wacana
Prima.

Trianto, T. (2010). Mendesain model pembelajaran inovatif-progresif: konsep, landasan, dan imlementasinya pada kurikulum tingkat satuan pendidikan (KTSP). Kencana.

Vygotskiū, L. S., \& Cole, M. (1978). Mind in society: The development of higher psychological processes. Harvard University Press.

Widodo, C. S., \& Jasmadi, J. (2008). Panduan menyusun bahan ajar berbasis kompetensi. Elex Media Komputindo.

Yuanita, P., Zulnaidi, H., \& Zakaria, E. (2018). The effectiveness of realistic mathematics education approach: The role of mathematical representation as mediator between mathematical belief and problem solving. PLOS ONE, 13(9), e0204847. https://doi.org/10.1371/journal.pone.0204 847 